\title{
EFEKTIVITAS PEMBAGIAN HARTA BERSAMA PASCA PERCERAIAN: STUDI KASUS PERKAWINAN POLIGAMI
}

\author{
Sufirman Rahman ${ }^{1}$, Nurul Qamar ${ }^{1}$, Muhammad Kamran ${ }^{2 *}$ \\ ${ }^{1}$ Dosen Fakultas Hukum, Universitas Muslim Indonesia, Makassar \\ ${ }^{2}$ Mahasiswa Magister Ilmu Hukum, Program Pascasarjana Universitas Muslim Indonesia, Makassar \\ *Penulis Korespondensi: Muhammad Kamran \\ Email Korespondensi: muhammadkamran030196@gmail.com
}

Received: 1 Maret 2020

Accepted: 23 Maret 2020

\begin{abstract}
Abstrak. Penelitian ini bertujuan untuk mengetahui dan memahami faktor-faktor apakah yang mempengaruhi efektivitas pembagian harta bersama pasca perceraian studi kasus perkawinan poligami di Pengadilan Agama kelas 1A Makassar. Penelitian ini menggunakan tipe penelitian hukum empiris atau (Socio Legal Study Research). Penelitian ini dilakukan di Kota Makassar. Hasil penelitian menunjukan bahwa efektivitas pembagian harta bersama pasca perceraian studi kasus perkawinan poligami dapat dilihat berdasarkan lima faktor, antara lain: faktor hukumnya; faktor penegakan hukum; faktor sarana atau fasilitas pendukung; faktor masyarakat; serta faktor kebudayaan. Perolehan data dari keseluruhan faktor menunjukkan hasil yang kurang efektif, antara lain: terdapat 65\% terkait faktor hukumnya; 72,5\% terkait faktor penegakan hukumnya; 60\% terkait faktor sarana atau fasilitas pendukung; 61,25\% terkait faktor masyarakat; serta $62,5 \%$ terkait faktor kebudayaan.
\end{abstract}

Kata Kunci:

Efektivitas;

Perkawinan;

Poligami.

artikel dengan akses terbuka dibawah lisensi CC BY -4.0

\section{PENDAHULUAN}

Berdasarkan Pasal 1 Undang-Undang Republik Indonesia Nomor 16 Tahun 2019 tentang Perubahan Atas Undang-Undang Nomor 1 Tahun 1974 tentang Perkawinan (selanjutnya disebut UU No. 16 Tahun 2019) mengartikan bahwa: ${ }^{1}$

"Perkawinan ialah ikatan lahir bathin antara seorang pria dengan seorang wanita sebagai suami isteri dengan tujuan membentuk keluarga (rumah tangga) yang bahagia dan kekal berdasarkan Ketuhanan Yang Mahaesa."

Selanjutnya, berdasarkan Pasal 3 ayat (1) UU No. 16 Tahun 2019 mengatur bahwa:

"Pada azasnya dalam suatu perkawinan seorang pria hanya boleh mempunyai seorang isteri. Seorang wanita hanya boleh mempunyai seorang suami."

${ }^{1}$ Lihat juga Arif Zunaidi. (2018). Kedudukan Harta Bersama Perkawinan Poligami. Mahakim: Journal of Islamic Family Law, Institut Agama Islam Negeri Kediri, 2(2), hlm. 91. 
Dari ketentuan di atas, perkawinan di Indonesia mendasarkan pada azas monogami, namun azas tersebut tidak bersifat mutlak. Hal ini dikarenakan berdasarkan Pasal 3 ayat (2) UU No. 16 Tahun 2019 mengatur bahwa "Pengadilan, dapat memberi izin kepada seorang suami untuk beristeri lebih dari seorang apabila dikehendaki oleh fihak-fihak yang bersangkutan." jo. Pasal 4 ayat (1) UU No. 16 Tahun 2019 mengatur bahwa "Dalam hal seorang suami akan beristeri lebih dari seorang, ..., maka ia wajib mengajukan permohonan kepada Pengadilan di daerah tempat tinggalnya." jo. Pasal 5 ayat (1) UU No. 16 Tahun 2019 mengatur bahwa untuk dapat mengajukan permohonan kepada Pengadilan, ... , harus dipenuhi syarat-syarat sebagai berikut:

a. adanya persetujuan dari isteri/isteri-isteri;

b. adanya kepastian bahwa suami mampu menjamin keperluan-keperluan hidup isteri-isteri dan anak-anak mereka;

c. adanya jaminan bahwa suami akan berlaku adil terhadap isteri-isteri dan anakanak mereka.

Dari ketentuan di atas, dapat disimpulkan bahwa pernikahan di Indonesia diharapkan berazas monogami dengan jalan mempersulit dan mempersempit keinginan para suami untuk mengajukan permohonan poligami, namun tidak dengan tujuan ingin menghilangkan penerapan poligami bagi masyarakat di Indonesia. ${ }^{2}$

Di era dewasa ini, ajaran agama Islam kerap disangkut-pautkan bahkan dianggap sebagai pelopor pelaksanaan poligami. Sekiranya masyarakat dapat lebih mengetahui dan memahami bahwa poligami dalam Islam merupakan tindakan dan perbuatan yang berada pada situasi darurat. Artinya, tindakan poligami tidak akan terlaksana dan menjadi sah sejauh kondisi rumah tangga sang suami berada dalam kondisi baikbaik saja bahkan memperlihatkan keharmonisan. ${ }^{3}$

Adapun perkawinan poligami merupakan syariat Islam dan akan berlaku sepanjang zaman hingga hari akhir. Poligami diperbolehkan dengan syarat sang suami memiliki kemampuan untuk adil diantara para istri, bila seorang suami memiliki lebih dari satu istri, wajib baginya untuk berlaku adil di antara mereka, dengan memberikan nafkah yang sama, memberi pakaian, tempat tinggal, dan waktu bermalam. ${ }^{4}$ Hal tersebut juga dapat diketahui dan dipahami dalam ayat Al-Qur'an Surah An-Nisa' ayat (3), bahwa:

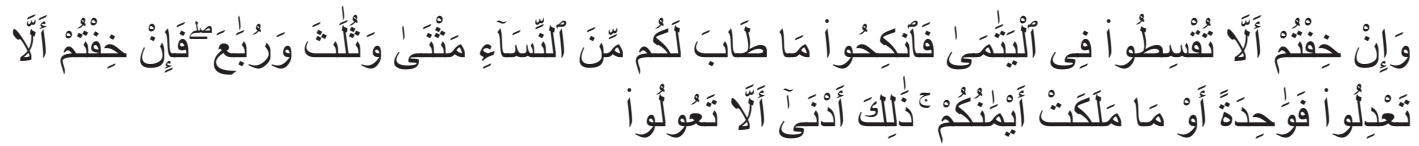

"Dan jika kamu khawatir tidak akan mampu berlaku adil terhadap (hak-hak) perempuan yatim (bilamana kamu menikahinya), maka nikahilah perempuan (lain) yang kamu senangi: dua, tiga atau empat. Tetapi jika kamu khawatir

\footnotetext{
${ }^{2}$ Mochammad Soleh Alaidrus. (2009). Pelaksanaan Pembagian Harta Perkawinan dalam Perkawinan Poligami (Studi di Pengadilan Agama Bekasi). Notarius, Universitas Diponegoro, 1(1), hlm. 1.

${ }^{3}$ M. Ali Hasan. (2003). Pedoman Hidup Berumah Tangga dalam Islam. Jakarta: Kencana Prenada Media Group, hlm. 269.

${ }^{4}$ Arij Abdurrahman As-Sanan. (2003). Memahami Keadilan dalam Poligami (Terj. oleh Ahmad Sahal Hasan). Jakarta: PT. Globalmedia Cipta Publishing, hlm. 25.
} 
tidak akan mampu berlaku adil, maka (nikahilah) seorang saja, atau hamba sahaya perempuan yang kamu miliki. Yang demikian itu lebih dekat agar kamu tidak berbuat zalim."

Di sisi lain, perkawinan merupakan suatu peristiwa hukum yang sangat penting dalam kehidupan masyarakat Indonesia. Konsekuensi hukum perkawinan itu tidak hanya menyangkut hubungan hukum antara calon suami isteri, tetapi juga dengan orang tua kedua belah pihak, saudara-saudara, bahkan keluarga-keluarga kedua belah pihak. Pada saat terjadinya perkawinan, pasangan suami isteri telah terikat sebuah keluarga sehingga sering terjadi antara suami isteri mencari perolehan bersama sehingga muncullah harta kekayaan dalam keluarga. Harta kekayaan dalam perkawinan bisa berupa harta yang diperoleh isteri maupun yang diperoleh suami pada saat perkawinan.

Berdasarkan Pasal 35 ayat (1) UU No. 16 Tahun 2019 mengatur bahwa "Harta benda yang diperoleh selama perkawinan menjadi harta bersama" jo. Pasal 1 huruf f Instruksi Presiden Republik Indonesia Nomor 1 Tahun 1991 tentang Penyebarluasan Kompilasi Hukum Islam (selanjutnya disebut Inpres No. 1 Tahun 1991) mengartikan bahwa:

"Harta kekayaan dalam perkawinan atau Syirkah adalah harta yang diperoleh baik sendiri-sendiriatau bersama suami-isteri selama dalam ikatan perkawinan berlangsung selanjutnya disebut harta bersama, tanpa mempersoalkan terdaftar atas nama siapapun."

Dari ketentuan di atas dapat diketahui bahwa terbentuknya harta bersama dalam perkawinan adalah sejak terjadinya pernikahan sampai dengan tanggal ikatan perkawinan itu putus. Selanjutnya, berdasarkan Pasal 38 UU No. 16 Tahun 2019 mengatur bahwa perkawinan dapat putus karena:

a. kematian;

b. perceraian; dan

c. atas keputusan pengadilan.

Dari ketentuan di atas memberikan suatu konsekuensi hukum, bahwa berakhirnya suatu hubungan pernikahan kerap menghadirkan perselisihan dimana menimbulkan dampak hukum yang mempengaruhi hak-hak dan kewajiban-kewajiban antara mantan suami maupun mantan istri serta anak yang lahir dari perkawinan yang sah tersebut. Demikian juga mengenai harta bersama/goni-gini yang diperoleh selama ikatan perkawinan berlangsung maupun harta bawaan dari masing-masing suami istri tersebut.

Di sisi lain berdasarkan fakta hukum khususnya dalam persidangan perceraian dalam perkawinan poligami di Pengadilan Agama kelas 1A Makassar, kerap ditemukan masalah yang dimana terjadi penyelundupan hak istri terdahulu oleh suami. Oleh karena fakta hukum tersebut, selain masalah pembagian dan pemisahan harta bersama, penting kiranya menyikapi dan mengungkap lebih dalam tentang faktor-faktor apa saja yang mempengaruhi efektivitas pembagian harta bersama pasca perceraian studi kasus perkawinan poligami. 
Berdasarkan uraian tersebut di atas, maka tujuan penelitian ini adalah untuk mengetahui dan memahami faktor-faktor apakah yang mempengaruhi efektivitas pembagian harta bersama pasca perceraian studi kasus perkawinan poligami di Pengadilan Agama kelas 1A Makassar.

\section{METODE}

Jenis penelitian ini adalah jenis penelitian hukum dengan tipe penelitian hukum empiris atau (Socio Legal Study Research). ${ }^{5}$ Penelitian ini dilakukan di Kota Makassar dan terdiri dari beberapa lokasi, antara lain di Pengadilan Agama Kelas 1A Makassar, di Kantor Advokat, di Kantor Notaris dan di pemukiman Ulama. Penentuan responden sebagai populasi penelitian berdasarkan karakternya, yang terdiri dari Hakim Pengadilan Agama Kelas 1A Makassar sebanyak 15; Panitera Pengadilan Agama Kelas 1A Makassar sebanyak 10; Juru Sita Pengadilan Agama Kelas 1A Makassar sebanyak 5 (lima); Advokat sebanyak 30; Notaris sebanyak 5 (lima); Ulama sebanyak 5 (lima); dan Masyarakat berperkara sebanyak 10 (sepuluh). Lebih lanjut, jenis dan sumber data yaitu terdiri dari data primer dan sekunder, dimana data primer diperoleh langsung di lokasi penelitian melalui proses wawancara, sedangkan data sekunder diperoleh dari hasil kajian dengan menggunakan bahan-bahan pustaka seperti Buku, Jurnal ilmiah, Artikel Ilmiah, Pidato Pengukuhan Guru Besar, Tesis, Peraturan Perundang-undangan, dokumen-dokumen resmi serta tulisan-tulisan lain yang mempunyai relevan dengan pembahasan penelitian ini. Adapun hasil penelitian merupakan analisis kualitatif dari output kuesioner yang berupa tabulasi frekuensi dan distribusi persentasi.

\section{HASIL DAN PEMBAHASAN}

Perkawinan sebagai perjanjian suci dalam membentuk keluarga antara seorang lakilaki dengan seorang perempuan. ${ }^{6}$ Perkawinan merupakan salah satu peristiwa hukum yang sangat penting dalam kehidupan masyarakat Indonesia secara luas. Hal ini disebabkan oleh karena perkawinan itu tidak hanya menyangkut hubungan hukum antara calon suami istri, tetapi juga menyangkut hubungan dengan orang tua kedua belah pihak, saudara-saudara, bahkan keluarga-keluarga kedua belah pihak.

Perkawinan berdasarkan agama Islam memiliki komponen-komponen ibadah, melangsungkan perkawinan berarti melangsungkan separuh dari ibadahnya dan berarti pula telah melengkapkan separuh dari agamanya. Perkawinan bertekad membina keluarga yang diliputi rasa saling cinta-mencintai dan rasa kasih sayang antara sesama anggota keluarga. ${ }^{7}$

Adapun salah satu praktik dari perkawinan ialah perkawinan poligami. Dalam aspek hukum perkawinan poligami tentunya juga membawa beberapa konsekuensi, di

\footnotetext{
${ }^{5}$ Nurul Qamar, et al. (2017). Metode Penelitian Hukum (Legal Research Methods). Makassar: CV. Social Politic Genius (SIGn), hlm. 52.

${ }^{6}$ Ahyuni Yunus. (2020). Hukum Perkawinan dan Itsbat Nikah: Antara Perlindungan dan Kepastian Hukum. Makassar: Humanities Genius, hlm. 27.

${ }^{7}$ Sirman Dahwal. (2017). Perbandingan Hukum Perkawinan. Bandung: CV. Mandar Maju, hlm. 17.
} 
antaranya menyangkut hak dan kewajiban suami dan istri maupun yang menyangkut harta kekayaan dalam perkawinan. ${ }^{8}$

Berdasarkan sudut pandangan Normatif dan Empiris atau das sollen (apa yang seharusnya) maupun das sein (sebagai fakta yang senyatanya), pelaksanaan pembagian harta bersama pasca perceraian studi kasus perkawinan poligami masih dipengaruhi oleh beberapa faktor sehingga ukuran efektifitas dalam pelaksanaan pembagian harta bersama pasca perceraian studi kasus perkawinan poligami masih kurang efektif. Hal ini dikarenakan oleh beberapa faktor sehingga ukuran derajat efektif masih belum terpenuhi.

Di sisi lain, perkawinan yang diatur dalam Hukum Islam dan Undang-undang Perkawinan dimana terdapat suatu mekanisme yang mempersulit terjadinya perceraian, tetapi tidak menutup kemungkinan pernikahan yang awal baik-baik saja terjadi keretakan dalam hubungan perkawinan yang tentu apabila tidak terjadi penyelesaian akan berdampak besar, yaitu berakibat terhadap putusnya suatu ikatan perkawinan.

Beberapa kejadian perceraian diakibatkan oleh permasalahan sederhana, seperti pertengkaran rumah tangga sehingga menimbulkan ketidakharmonisan, ketidakcocokan maupun ketidakpercayaan antara suami istri. Dari kejadian perceraian tersebut, sering kali antara suami dan istri mempersoalkan hartanya terutama di dalam pembagian harta bersama atau harta Gono Gini. Sebagaimana telah dipaparkan pada pendahuluan dimana berdasarkan Pasal 38 UU No. 16 Tahun 2019 mengatur bahwa perkawinan dapat putus karena: ${ }^{9}$
a. kematian;
b. perceraian; dan
c. atas keputusan pengadilan.

Apabila melihat realita hukum saat ini, salah satu permasalahan perkawinan khususnya perkawinan poligami dimana masih banyak menimbulkan pro (merespon baik atau positif) dan kontra (merespon buruk atau negatif), masalah hukum yang sering muncul yaitu masalah pembagian harta bersama pasca perceraian dan faktorfaktor yang mempengaruhi efektivitas pembagian harta bersama pasca perceraian studi kasus perkawinan poligami. Adapun efektivitas hukum dapat diartikan bahwa: ${ }^{10}$

"Pertama-tama harus dapat menilai sejauh mana aturan hukum itu ditaati atau tidak ditaati oleh masyarakatnya. Jika suatu aturan hukum ditaati oleh sebagian besar masyarakatnya, maka dapat dikatakan bahwa aturan hukum berjalan efektif".

${ }^{8}$ Desi Fitrianti. (2017). Harta Bersama dalam Perkawinan Poligami Menurut Undang-Undang Nomor 1 Tahun 1974 dan Hukum Islam. Jurnal Intelektualita: Keislaman, Sosial dan Sains, Universitas Islam Negeri Raden Fatah Palembang, 6(1), hlm. 89.

${ }^{9}$ Lihat juga Ongky Alexander. (2019). Efektivitas Pembagian Harta Gono - Gini Pasca Perceraian dalam Persfektif Yuridis Sosiologis. El-Ghiroh: Jurnal Studi Keislaman, Sekolah Tinggi Agama Islam Bumi Silampari, 16(1), hlm. 120 - 121

${ }^{10}$ Salim H. S. \& Erlies Septiana Nurbani. (2013). Penerapan Teori Hukum pada Penelitian Tesis dan Disertasi. Jakarta: PT. Raja Grafindo Persada, hlm. 375. 
Efektivitas berasal dari kata efektif yang mengandung pengertian dicapainya keberhasilan dalam mencapai tujuan yang telah ditetapkan. Efektivitas selalu terkait dengan hubungan antara hasil yang diharapkan dengan hasil yang sesungguhnya dicapai. Efektivitas adalah kemampuan melaksanakan tugas, fungsi (operasi kegiatan program atau misi) daripada suatu organisasi atau sejenisnya yang tidak adanya tekanan atau ketegangan diantara pelaksanaannya. Jadi efektivitas hukum menurut pengertian di atas mengartikan bahwa indikator efektivitas dalam arti tercapainya sasaran atau tujuan yang telah ditentukan sebelumnya merupakan sebuah pengukuran dimana suatu target telah tercapai sesuai dengan apa yang telah direncanakan. ${ }^{11}$

Selanjutnya, efektivitas dapat dinilai berdasarkan faktor apa saja yang mempengaruhi keberhasilan atau kegagalan berdasarkan target capaian yang telah direncanakan sebelumnya. Lebih lanjut, efektif atau tidaknya suatu aturan tertulis atau ketentuan Undang-Undang yang berlaku nasional, ditentukan oleh lima faktor, antara lain yaitu: ${ }^{12}$

1. Faktor hukumnya (peraturan berupa norma-norma/kaidah-kaidah hukum);

2. Faktor penegakan hukum (pembentukan atau penerapan hukum);

3. Faktor sarana ataupun fasilitas mendukung efektifitasnya penegak hukum;

4. Faktor masyarakat (lingkungan tempat penerapan aturan hukum tersebut);

5. Faktor kebudayaan (kebudayaan masyarakat yang masih tetap hidup dan dipertahankan).

Kelima faktor di atas secara integratif dan tersistematis akan menentukan apakah sebuah aturan itu dapat efektif berlaku di masyarakat atau tidak. Sebagaimana menurut teori sociological jurisprudence bahwa: ${ }^{13}$

"Hukum yang baik adalah hukum yang sesuai dengan hukum yang hidup di dalam masyarakat. Sesuai di sini berarti bahwa hukum itu mencerminkan nilai-nilai yang hidup di dalam masyarakat."

Dari teori sociological jurisprudence, maka efektivitas norma ditentukan oleh taraf kepatuhan masyarakat terhadap hukum, termasuk para penegak hukumnya. Terdapat ungkapan yang begitu familiar, bahwa: ${ }^{14}$

"Taraf kepatuhan yang tinggi adalah indikator dari berfungsinya suatu sistem hukum, dan berfungsinya hukum merupakan indikator bahwa hukum tersebut mencapai tujuan hukum yaitu berusaha untuk mempertahankan dan melindungi segenap masyarakatnya."

Berulang kali kita melihat bahwa di dalam masyarakat, hukum yang telah dibuat kelihatan tidak efektif, permasalahan efektivitas hukum memiliki hubungan erat dengan permasalahan penerapan/pelaksanaan, pelaksanaan dan penegakan hukum

\footnotetext{
${ }^{11}$ Nur Fitryani Siregar. (2018). Efektivitas Hukum. Al-Razi: Jurnal Ilmu Pengetahuan dan Kemasyarakatan, Sekolah Tinggi Agama Islam Barumun Raya, 18(2), hlm. 2 - 3.

${ }^{12}$ Soerjono Soekanto. (2016). Faktor-Faktor yang Mempengaruhi Penegakan Hukum. Jakarta: PT. Raja Grafindo Persada, hlm. 8.

${ }^{13}$ Salim H. S. \& Erlies Septiana Nurbani. (2013). Op. Cit., hlm. 32.

${ }^{14}$ Soerjono Soekanto. (1985). Efektivikasi Hukum dan Peranan Sanksi. Jakarta: PT. Remaja Rosdakarya, hlm. 7.
} 
dalam masyarakat demi terciptanya tujuan hukum. Artinya hukum benar-benar berlaku secara filosofis, yuridis dan sosiologis."15

Berdasarkan penelitian yang telah dilakukan berkenaan dengan faktor-faktor yang mempengaruhi efektivitas pembagian harta bersama pasca perceraian studi kasus perkawinan poligami di Pengadilan Agama Kelas 1A Makassar, maka kelima faktor akan diuraikan satu persatu, antara lain sebagai berikut:

\section{Faktor Hukum}

Hasil perolehan data dari proses wawancara dengan responden terkait efektivitas pembagian harta bersama pasca perceraian studi kasus perkawinan poligami berdasarkan faktor hukumnya dapat dilihat pada tabel di bawah ini.

Tabel 1. Pengaruh Faktor Hukumnya

\begin{tabular}{c|l|c|c}
\hline \hline No. & Pernyataan/Kategori & Frekuensi & Persentasi \\
\hline \hline 1. & Efektif & 28 & $35 \%$ \\
\hline 2. & Kurang Efektif & 52 & $65 \%$ \\
\hline 3. & Tidak Efektif & 0 & $0 \%$ \\
\hline \hline \multicolumn{2}{c|}{ Jumlah } & $\mathbf{8 0}$ & $\mathbf{1 0 0 \%}$ \\
\hline \hline
\end{tabular}

Sumber: Hasil Kuesioner Tahun 2019 - 2020

Dari tabel di atas menunjukkan bahwa terdapat 28 orang atau 35\% dari total responden menyatakan efektif; 52 orang atau 65\% menyatakan kurang efektif; sedangkan tidak terdapat pernyataan responden yang mengatakan tidak efektif. Dapat dinilai bahwa efektivitas pembagian harta bersama pasca perceraian studi kasus perkawinan poligami berdasarkan faktor hukumnya masih kurang efektif.

Adapun kurang efektifnya faktor hukum dapat dinilai sebagai bentuk gangguan dari para penegak hukum dan Peraturan Perundang-Undangan, sehingga mengakibatkan beberapa penyebab, antara lain: ${ }^{16}$

1) Asas-asas berlakunya Peraturan Perundang-Undangan tidak diikuti;

2) Masih tidak adanya aturan penerapan yang benar-benar diperlukan buat melaksanakan aturan Perundang-Undangan;

3) Ketidakjelasan artian kata-kata di dalam Peraturan Perundang-Undangan yang menimbulkan kesimpangsiuran ketika interpretasi maupun pelaksanaannya.

Di sisi lain, jika melihat peraturan perundang-undangan, pelaksanaan pembagian harta bersama pasca perceraian studi kasus perkawinan poligami telah diatur dalam Pasal 94 Inpres No. 1 Tahun 1991; Pasal 65 UU No. 16 Tahun 2019; bahkan lebih spesifik diatur dalam Surat Keputusan Mahkamah Agung Nomor: KMA/032/ SK/IV/2006. Namun, berdasarkan sifat dari sebuah Surat Keputusan jelas berbeda

\footnotetext{
${ }^{15}$ Syamsuddin Pasamai. (2011). Sosiologi dan Sosiologi Hukum. Makassar: PT. Umitoha Ukhuwah Grafika, hlm. 201.

${ }^{16}$ Soerjono Soekanto. (2016). Op. Cit., hlm. 17 - 18.
} 
dengan sifat dari Aturan Undang-Undang.

\section{Faktor Penegakan Hukum}

Hasil perolehan data dari proses wawancara dengan responden terkait efektivitas pembagian harta bersama pasca perceraian studi kasus perkawinan poligami berdasarkan faktor penegakan hukumnya dapat dilihat pada tabel di bawah ini.

Tabel 2. Pengaruh Faktor Penegakan Hukum

\begin{tabular}{c|l|c|c}
\hline \hline No. & Pernyataan/Kategori & Frekuensi & Persentasi \\
\hline \hline 1. & Efektif & 21 & $26,25 \%$ \\
\hline 2. & Kurang Efektif & 58 & $72,5 \%$ \\
\hline 3. & Tidak Efektif & 1 & $1,25 \%$ \\
\hline \hline \multicolumn{2}{c}{ Jumlah } & $\mathbf{8 0}$ & $\mathbf{1 0 0 \%}$ \\
\hline \hline
\end{tabular}

Sumber: Hasil Kuesioner Tahun 2019 - 2020

Dari tabel di atas menunjukkan bahwa terdapat 21 orang atau 26,25\% dari total responden menyatakan efektif; 58 orang atau 72,5\% menyatakan kurang efektif; sedangkan 1 orang atau 1,25\% menyatakan tidak efektif. Dapat dinilai bahwa efektivitas pembagian harta bersama pasca perceraian studi kasus perkawinan poligami berdasarkan faktor penegakan hukumnya masih kurang efektif.

Adapun kurang efektifnya faktor penegakan hukum dapat dinilai bahwa penegak hukum tidaklah sekedar untuk menerapkan suatu peraturan perundang-undangan ataupun Putusan hakim. Tetapi dalam hal ini, permasalahan utama yang menyerang penegak hukum yaitu ditemukan dalam faktor-faktor yang mempengaruhinya secara terang-terangan ataupun secara tidak terang-terangan. Faktor-faktor tersebut memiliki pengertian yang netral sehingga dapat mendatangkan akibat positif (baik) ataupun akibat negatif (buruk). selanjutnya, faktor penegak hukum dapat menciptakan kondisi dimana suatu norma hukum sungguh-sungguh dapat berjalan dengan baik. Lebih lanjut, penegak hukum tidak boleh bertindak sewenang-sewenang dalam melaksanakan fungsinya, mereka pun mesti mengamati etika yang berlaku dalam cakupan profesinya. Adapun penegakan hukum dapat diartikan bahwa: ${ }^{17}$

"Suatu proses untuk mewujudkan keinginan-keinginan hukum menjadi kenyataan. Yang disebut keinginan hukum di sini tidak lain adalah pikiran-pikiran badan pembuat Undang-Undang yang dirumuskan dalam peraturan hukum, Peraturan hukum itu, Perumusan pemikiran pembuat hukum yang dituangkan dalam peraturan hukum akan turut menentukan bagaimana penegakan hukum itu dijalankan."

Penegakan hukum itu pada prinsipnya adalah penegakan inspirasi ataupun teori-teori tentang keadilan, kebenaran, kemanfaatan sosial dan sebagainya. Jadi

${ }^{17}$ Zainab Ompu Jainah. (2012). Penegakan Hukum dalam Masyarakat. Journal of Rural and Development, Universitas Sebelas Maret, 3(2), hlm. 165. 
penegakan hukum adalah tindakan untuk menciptakan inspirasi ataupun teoriteori menjadi kenyataan. ${ }^{18}$

Tanggung jawab dan profesional hukum lahir dengan adanya kesalahan atau kekhilafan nyata yang dilakukan oleh penegak hukum (melanggar rambu-rambu hukum) baik pidana dan atau perdata, sehingga dituntut pertanggungjawaban baik dari segi pidana dan ataupun perdata. ${ }^{19}$ Adapun dalam penegakan hukum dapat dikategorisasi berdasarkan tiga unsur, antara lain: ${ }^{20}$

1) Kepastian norma (rechtssicherheit);

2) Manfaat (zweckmassigkeit);

3) Keadilan (gerechtigkeit).

Dari tiga unsur tersebut di atas, yang harus diutamakan oleh penegak hukum adalah memberikan rasa keadilan kepada masyarakat, karena masyarakat tentunya menginginkan rasa keadilan mengenai masalah hukum yang sementara dihadapinya, setelah itu penegak hukum harus melihat dari segi kepastian hukum, kemudian kemanfaatan. ${ }^{21}$

\section{Faktor Sarana atau Fasilitas Pendukung}

Hasil perolehan data dari proses wawancara dengan responden terkait efektivitas pembagian harta bersama pasca perceraian studi kasus perkawinan poligami berdasarkan faktor sarana atau fasilitas pendukung dapat dilihat pada tabel di bawah ini.

Tabel 3. Pengaruh Faktor Sarana atau Fasilitas Pendukung

\begin{tabular}{c|l|c|c}
\hline \hline No. & Pernyataan/Kategori & Frekuensi & Persentasi \\
\hline \hline 1. & Efektif & 31 & $38,75 \%$ \\
\hline 2. & Kurang Efektif & 48 & $60 \%$ \\
\hline 3. & Tidak Efektif & 1 & $1,25 \%$ \\
\hline \hline \multicolumn{2}{c}{ Jumlah } & $\mathbf{8 0}$ & $\mathbf{1 0 0 \%}$ \\
\hline \hline
\end{tabular}

Sumber: Hasil Kuesioner Tahun $2019-2020$

Dari tabel di atas menunjukkan bahwa terdapat 31 orang atau 38,75\% dari total responden menyatakan efektif; 48 orang atau 60\% menyatakan kurang efektif; sedangkan 1 orang atau 1,25\% menyatakan tidak efektif. Dapat dinilai bahwa efektivitas pembagian harta bersama pasca perceraian studi kasus perkawinan poligami berdasarkan faktor sarana atau fasilitas pendukung masih kurang efektif.

Mesti dipahami bersama bahwa sarana atau fasilitas pendukung dalam efektifitas suatu capaian merupakan salah satu faktor utama, sebagaimana menurut Soerjono

\footnotetext{
${ }^{18}$ Satjipto Rahardjo. (2010). Masalah Penegakan Hukum: Suatu Tinjauan Sosiologis. Bandung: Sinar Baru, hlm. 15

${ }^{19}$ Sufirman Rahman \& Nurul Qamar. (2014). Etika Profesi Hukum. Makassar: Pustaka Refleksi, hlm. 5 - 6.

${ }^{20}$ Sudikno Mertokusumo. (1999). Mengenal Hukum: Suatu Pengantar. Yogyakarta: Liberty, hlm. 145.

${ }^{21}$ Arif Zunaidi. (2018). Op. Cit., hlm. 92.
} 
Soekanto bahwa: ${ }^{22}$

"Tanpa adanya suatu sarana dan fasilitas tertentu, maka tidak mungkin penegakan hukum akan berlangsung dengan lancar. Sarana atau fasilitas tersebut, antara lain, mencakup tenaga manusia yang berpendidikan dan terampil, organisasi yang baik, peralatan yang memadai, keuangan yang cukup, dan seterusnya. Kalau hal-hal itu tidak terpenuhi, maka mustahil penegakan hukum akan mencapai tujuannya."

\section{Faktor Masyarakat}

Hasil perolehan data dari proses wawancara dengan responden terkait efektivitas pembagian harta bersama pasca perceraian studi kasus perkawinan poligami berdasarkan faktor masyarakatnya dapat dilihat pada tabel di bawah ini.

Tabel 4. Pengaruh Faktor Masyarakat

\begin{tabular}{c|l|c|c}
\hline \hline No. & Pernyataan/Kategori & Frekuensi & Persentasi \\
\hline \hline 1. & Efektif & 28 & $35 \%$ \\
\hline 2. & Kurang Efektif & 49 & $61,25 \%$ \\
\hline 3. & Tidak Efektif & 3 & $3,75 \%$ \\
\hline \hline \multicolumn{2}{r|}{ Jumlah } & $\mathbf{8 0}$ & $\mathbf{1 0 0 \%}$ \\
\hline \hline
\end{tabular}

Sumber: Hasil Kuesioner Tahun 2019 - 2020

Dari tabel di atas menunjukkan bahwa terdapat 28 orang atau 35\% dari total responden menyatakan efektif; 49 orang atau 61,25\% menyatakan kurang efektif; sedangkan 3 orang atau 3,75\% menyatakan tidak efektif. Dapat dinilai bahwa efektivitas pembagian harta bersama pasca perceraian studi kasus perkawinan poligami berdasarkan faktor masyarakatnya masih kurang efektif.

Adapun kurang efektifnya faktor masyarakat dapat dinilai dari ketidaksadaran ataupun ketidakpatuhan masyarakat tentang hukum dan perundang-undangan. Dalam hal ini sebaik dan sebagus apapun peraturan perundang-undangan, maka aturan tersebut tetap kurang efektif apabila tidak ditunjang oleh kesadaran dan kepatuhan hukum warga Negara. ${ }^{23}$ Selanjutnya, Soerjono Soekanto mengemukakan bahwa: ${ }^{24}$

"Penegakan hukum berasal dari masyarakat, maka dengan demikian bertujuan untuk mencapai kedamaian di dalam masyarakat. Oleh karena itu, dipandang dari sudut tertentu, maka masyarakat dapat mempengaruhi penegakan hukum tersebut."

Lebih lanjut, kesadaran dan kepatuhan masyarakat merupakan faktor yang sangat penting, dikarenakan bahwa: ${ }^{25}$

\footnotetext{
${ }^{22}$ Soerjono Soekanto. (2016). Op. Cit., hlm. 37.

${ }^{23}$ Ramly Hutabarat. (1985). Persamaan di Hadapan Hukum (Equality Before the Law) di Indonesia. Jakarta: Ghalia Indonesia, hlm. 78.

${ }^{24}$ Soerjono Soekanto. (2016). Op. Cit., hlm. 45.

${ }^{25}$ Ellya Rosana. (2014). Kepatuhan Hukum sebagai Wujud Kesadaran Hukum Masyarakat. Jurnal Tapis: Jurnal Teropong Aspirasi Politik Islam, Universitas Islam Negeri Raden Intan Lampung, 10(1), hlm. 69.
} 
"Tegaknya suatu peraturan hukum baru akan menjadi kenyataan bilamana didukung oleh adanya kesadaran hukum dari segenap warga masyarakat itu sendiri. Kesadaran bagi berlakunya hukum adalah dasar bagi dilaksanakannya hukum itu sendiri."

\section{Faktor Kebudayaan}

Hasil perolehan data dari proses wawancara dengan responden terkait efektivitas pembagian harta bersama pasca perceraian studi kasus perkawinan poligami berdasarkan faktor kebudayaannya dapat dilihat pada tabel di bawah ini.

Tabel 5. Pengaruh Faktor Kebudayaan

\begin{tabular}{c|l|c|c}
\hline \hline No. & Pernyataan/Kategori & Frekuensi & Persentasi \\
\hline \hline 1. & Efektif & 25 & $31,25 \%$ \\
\hline 2. & Kurang Efektif & 50 & $62,5 \%$ \\
\hline 3. & Tidak Efektif & 5 & $6,25 \%$ \\
\hline \hline \multicolumn{2}{c|}{ Jumlah } & $\mathbf{8 0}$ & $\mathbf{1 0 0 \%}$ \\
\hline \hline
\end{tabular}

Sumber: Hasil Kuesioner Tahun 2019 - 2020

Dari tabel di atas menunjukkan bahwa terdapat 25 orang atau 31,25\% dari total responden menyatakan efektif; 50 orang atau 62,5\% menyatakan kurang efektif; sedangkan 5 orang atau 6,25\% menyatakan tidak efektif. Dapat dinilai bahwa efektivitas pembagian harta bersama pasca perceraian studi kasus perkawinan poligami berdasarkan faktor kebudayaannya masih kurang efektif.

Adapun kurang efektifnya faktor kebudayaan dapat dinilai dari miss-interpretasinya masyarakat dalam menilai keterhubungan antara hukum positif dengan norma kebudayaan. Pada hakikatnya, norma kebudayaan memiliki sifat yang universal dan hidup di tengah masyarakat setempat. Adapun sifat dari kebudayaan antara lain yaitu: ${ }^{26}$

1) Kebudayaan lahir dan muncul dari perbuatan manusia, dan ditransformasikan melalui perbuatan manusia itu sendiri;

2) Kebudayaan telah ada lebih dulu daripada generasi tertentu, dan tidak akan musnah seiring habisnya usia generasi tersebut;

3) Kebudayaan menjadi kepentingan bagi manusia, dan menjadi pedoman bagi tingkah lakunya;

4) Kebudayaan melingkupi aturan-aturan yang perwujudannya berupa kewajiban-kewajiban, perbuatan-perbuatan yang sesuai dan yang tidak sesuai, dan tentang boleh tidaknya suatu perbuatan dilakukan.

Berdasarkan penjabaran sifat kebudayaan di atas, dibutuhkan artikulasi yang tepat dari ketetapan dalam pasal-pasal peraturan perundang-undangan mengingat

${ }^{26}$ Elly M. Setiadi, Kama A. Hakam, \& Ridwan Effendi. (2011). Ilmu Sosial dan Budaya Dasar. Jakarta: Kencana Prenada Media Group, hlm. 33 - 34. 
bahwa sifat kebudayaan merupakan marwah dari peraturan perundang-undangan itu sendiri, sehingga dengan pengartikulasian aturan yang tepat di kalangan masyarakat, maka peraturan perundang-undangan tersebut dapat berjalan secara efektif. Sebagaimana Soerjono Soekanto mengemukakan bahwa: ${ }^{27}$

"Kebudayaan Indonesia yang mendasari hukum adat yang berlaku. Hukum adat tersebut merupakan hukum kebiasaan yang berlaku dikalangan rakyat terbanyak. Di samping itu, berlaku pula hukum tertulis (perundangundangan) yang timbul dari golongan tertentu dalam masyarakat yang mempunyai kekuasaan dan wewenang yang resmi. Hukum perundangundangan tersebut harus dapat mencerminkan nilai-nilai yang menjadi dasar dari hukum adat supaya hukum perundang-undangan tersebut dapat berlaku secara efektif."

\section{KESIMPULAN}

Dari uraian hasil dan pembahasan di atas, efektivitas pembagian harta bersama pasca perceraian studi kasus perkawinan poligami dapat dilihat berdasarkan lima faktor, antara lain: faktor hukumnya; faktor penegakan hukum; faktor sarana atau fasilitas pendukung; faktor masyarakat; serta faktor kebudayaan. Perolehan data dari keseluruhan faktor menunjukkan hasil yang kurang efektif, antara lain: terdapat 65\% terkait faktor hukumnya; 72,5\% terkait faktor penegakan hukumnya; 60\% terkait faktor sarana atau fasilitas pendukung; 61,25\% terkait faktor masyarakat; serta $62,5 \%$ terkait faktor kebudayaan. Dibutuhkan keseriusan, khususnya bagi penegak hukum dalam menjalankan peranannya, serta diharapkan kepada seluruh stakeholder terkait untuk menyosialisasikan aturan terkait tata cara pembagian harta bersama pasca perceraian.

\section{UCAPAN TERIMA KASIH}

Pertama-tama Penulis memberikan ucapan terima kasih yang sebesar-besarnya kepada semua pihak yang telah memberikan saran maupun petunjuk di tengah kesibukannya dalam merampungkan penyusunan artikel ini, terkhusus ucapan terima kasih kepada Sufirman Rahman dan Nurul Qamar selaku pembimbing bagi penulis dalam menyelesaikan Studi Magister Ilmu Hukum. Semoga kontribusi yang telah diberikan kepada penulis bernilai ibadah.

\section{REFERENSI}

A. Rahman Rahim. (1992). Nilai-Nilai Utama Kebudayaan Bugis. Ujung Pandang: Hasanuddin University Press.

A. Zainal Abidin Farid. (1983). Persepsi Orang Bugis Makassar tentang Hukum, Negara dan Dunia Luar. Bandung: PT. Alumni.

A. Zainal Abidin Farid. (2017). Capita Selecta: Kebudayaan Sulawesi Selatan. Makassar: CV. Social Politic Genius (SIGn).

${ }^{27}$ Soerjono Soekanto. (2016). Op. Cit., hlm. 64 - 65. 
A. Zainal Abidin Farid. (2017). Capita Selecta: Sejarah Sulawesi Selatan. Makassar: CV. Social Politic Genius (SIGn).

Ahmad Khumaidi Ja'far. (2012). Teori-Teori Pemberlakuan Hukum Islam di Indonesia. Asas, Universitas Islam Negeri Raden Intan Lampung, 4(2), hlm. 1 - 6.

Ahyuni Yunus. (2020). Hukum Perkawinan dan Itsbat Nikah: Antara Perlindungan dan Kepastian Hukum. Makassar: Humanities Genius.

Arif Zunaidi. (2018). Kedudukan Harta Bersama Perkawinan Poligami. Mahakim: Journal of Islamic Family Law, Institut Agama Islam Negeri Kediri, 2(2), hlm. 91 106. doi: http://dx.doi.org/10.30762/mh.v2i2.975

Arij Abdurrahman As-Sanan. (2003). Memahami Keadilan dalam Poligami (Terj. oleh Ahmad Sahal Hasan). Jakarta: PT. Globalmedia Cipta Publishing.

Bahtiar Bahtiar. (2019). Hubungan Politik Antar Kerajaan: Gowa Dengan Bone, Soppeng, Wajo (Tellumpocco). Walasuji: Jurnal Sejarah dan Budaya, Balai Pelestarian Nilai Budaya Makassar, 10(2), hlm. 251 - 267. doi: https://doi.org/10.36869/wjsb. v10i2.12

Barend ter Haar. (2011). Asas-Asas dan Susunan Hukum Adat (Terj. oleh Freddy Tengker). Bandung: CV. Mandar Maju.

Cornelis van Vollenhoven. (1934). Staatsrecht Overzee. Laiden: Stenfert Kroese.

Desi Fitrianti. (2017). Harta Bersama dalam Perkawinan Poligami Menurut UndangUndang Nomor 1 Tahun 1974 dan Hukum Islam. Jurnal Intelektualita: Keislaman, Sosial dan Sains, Universitas Islam Negeri Raden Fatah Palembang, 6(1), hlm. 83 - 102. doi: https://doi.org/10.19109/intelektualita.v6i1.1302

Elly M. Setiadi, Kama A. Hakam, \& Ridwan Effendi. (2011). Ilmu Sosial dan Budaya Dasar. Jakarta: Kencana Prenada Media Group.

Ellya Rosana. (2014). Kepatuhan Hukum sebagai Wujud Kesadaran Hukum Masyarakat. Jurnal Tapis: Jurnal Teropong Aspirasi Politik Islam, Universitas Islam Negeri Raden Intan Lampung, 10(1), hlm. 61 - 84. doi: https://doi.org/10.24042/tps. v10i1.1600

Hazairin. (1974). Tujuh Serangkai Tentang Hukum. Jakarta: Tintamas.

Instruksi Presiden Republik Indonesia Nomor 1 Tahun 1991 tentang Penyebarluasan Kompilasi Hukum Islam.

Irwan Abbas. (2013). Pappaseng: Kearifan Lokal Manusia Bugis yang Terlupakan. Sosiohumaniora: Jurnal Ilmu-Ilmu Sosial dan Humaniora, Universitas Padjadjaran, 15(3), hlm. 272 - 284. doi: https://doi.org/10.24198/sosiohumaniora. v15i3.5752

Lawrence M. Friedman. (2008). Sistem Hukum: Perspektif Ilmu Sosial (Terj. oleh M. Khozim). Bandung: Nusa Media.

M. Ali Hasan. (2003). Pedoman Hidup Berumah Tangga dalam Islam. Jakarta: Kencana Prenada Media Group. 
Mattulada. (1998). Sejarah, Masyarakat, dan Kebudayaan Sulawesi Selatan. Ujung Pandang: Hasanuddin University Press.

Mochammad Soleh Alaidrus. (2009). Pelaksanaan Pembagian Harta Perkawinan dalam Perkawinan Poligami (Studi di Pengadilan Agama Bekasi). Notarius, Universitas Diponegoro, 1(1), hlm. 1 - 18.

Muhamad Hadis Badewi. (2019). Nilai Siri' dan Pesse dalam Kebudayaan BugisMakassar, dan Relevansinya terhadap Penguatan Nilai Kebangsaan. JSW (Jurnal Sosiologi Walisongo), Universitas Islam Negeri Walisongo Semarang, 3(1), hlm. 79 - 96. doi: http://dx.doi.org/10.21580/jsw.2019.3.1.3291

Muhammad Yusuf. (2013). Relevansi Nilai-Nilai Budaya Bugis dan Pemikiran Ulama Bugis: Studi atas Pemikirannya dalam Tafsir Berbahasa Bugis Karya MUI Sulsel. El-Harakah: Jurnal Budaya Islam, Universitas Islam Negeri Maulana Malik Ibrahim, 15(2), hlm. 199 - 216. doi: http://dx.doi.org/10.18860/el.v15i2.2766

Nur Fitryani Siregar. (2018). Efektivitas Hukum. Al-Razi: Jurnal Ilmu Pengetahuan dan Kemasyarakatan, Sekolah Tinggi Agama Islam Barumun Raya, 18(2), hlm. 1 - 16.

Nurul Qamar, et al. (2017). Metode Penelitian Hukum (Legal Research Methods). Makassar: CV. Social Politic Genius (SIGn).

Nurul Qamar, et al. (2018). Menguak Nilai Kearifan Lokal Bugis Makassar: Perspektif Hukum dan Pemerintahan. Makassar: CV. Social Politic Genius (SIGn).

Ongky Alexander. (2019). Efektivitas Pembagian Harta Gono - Gini Pasca Perceraian dalam Persfektif Yuridis Sosiologis. El-Ghiroh: Jurnal Studi Keislaman, Sekolah Tinggi Agama Islam Bumi Silampari, 16(1), hlm. 113 - 129. doi: https://doi. org/10.37092/el-ghiroh.v16i01.70

Peraturan Pemerintah Republik Indonesia Nomor 9 Tahun 1975 tentang Pelaksanaan Undang-Undang Nomor 1 Tahun 1974 tentang Perkawinan. Lembaran Negara Republik Indonesia Tahun 1975 Nomor 12. Tambahan Lembaran Negara Republik Indonesia Nomor 3050.

R. A. Kern. (1989). I La Galigo: Cerita Bugis (Terj. oleh La Side \& Sagimun Mulus Dumadi). Yogyakarta: UGM Press.

R. Soepomo. (1970). Hubungan Individu dan Masyarakat dalam Hukum Adat. Jakarta: PT. Pradnya Paramita.

Ramly Hutabarat. (1985). Persamaan di Hadapan Hukum (Equality Before the Law) di Indonesia. Jakarta: Ghalia Indonesia.

Salim H. S. \& Erlies Septiana Nurbani. (2013). Penerapan Teori Hukum pada Penelitian Tesis dan Disertasi. Jakarta: PT. Raja Grafindo Persada.

Sarah Sarmila Begem, Nurul Qamar, \& Hamza Baharuddin. (2019). Sistem Hukum Penyelesaian Pelanggaran Hak Asasi Manusia (HAM) Berat Melalui Mahkamah Pidana Internasional. SIGn Jurnal Hukum, CV. Social Politic Genius (SIGn), 1(1), hlm. 1 - 17. doi: https://doi.org/10.37276/sjh.v1i1.28

Satjipto Rahardjo. (2010). Masalah Penegakan Hukum: Suatu Tinjauan Sosiologis. Bandung: Sinar Baru. 
Sayuti Thalib. (1980). Receptio A Contrario: Hubungan Hukum Adat dengan Hukum Islam. Jakarta: PT. Bina Aksara.

Sirman Dahwal. (2017). Perbandingan Hukum Perkawinan. Bandung: CV. Mandar Maju.

Soerjono Soekanto, Edie T. Hendratno, \& T. H. Sardjito. (1984). Antropologi Hukum: Proses Pengembangan Ilmu Hukum Adat. Jakarta: Rajawali Pers.

Soerjono Soekanto. (1985). Efektivikasi Hukum dan Peranan Sanksi. Jakarta: PT. Remaja Rosdakarya.

Soerjono Soekanto. (1987). Hubungan Hukum Adat dengan Hukum Islam. Jurnal Hukum \& Pembangunan, Universitas Indonesia, 17(2), hlm. 152 - 162. doi: http:// dx.doi.org/10.21143/jhp.vol17.no2.1300

Soerjono Soekanto. (2016). Faktor-Faktor yang Mempengaruhi Penegakan Hukum. Jakarta: PT. Raja Grafindo Persada.

Sudikno Mertokusumo. (1999). Mengenal Hukum: Suatu Pengantar. Yogyakarta: Liberty.

Sufirman Rahman \& Nurul Qamar. (2014). Etika Profesi Hukum. Makassar: Pustaka Refleksi.

Syamsuddin Pasamai. (2011). Sosiologi dan Sosiologi Hukum. Makassar: PT. Umitoha Ukhuwah Grafika.

Syofyan Hadi. (2017). Hukum Positif dan The Living Law (Eksistensi dan Keberlakuannya dalam Masyarakat). DIH: Jurnal Ilmu Hukum, Universitas 17 Agustus 1945 Surabaya, 13(26), hlm. 259 - 266. doi: https://doi.org/10.30996/ dih.v0i0.1588

Undang-Undang Republik Indonesia Nomor 1 Tahun 1974 tentang Perkawinan. Lembaran Negara Republik Indonesia Tahun 1974 Nomor 1. Tambahan Lembaran Negara Republik Indonesia Nomor 3019.

Undang-Undang Republik Indonesia Nomor 16 Tahun 2019 tentang Perubahan Atas Undang-Undang Nomor 1 Tahun 1974 tentang Perkawinan. Lembaran Negara Republik Indonesia Tahun 2019 Nomor 186. Tambahan Lembaran Negara Republik Indonesia Nomor 6401.

Zainab Ompu Jainah. (2012). Penegakan Hukum dalam Masyarakat. Journal of Rural and Development, Universitas Sebelas Maret, 3(2), hlm. 165 - 172.

Sufirman Rahman, Nurul Qamar, \& Muhammad Kamran. (2020). Efektivitas : I Pembagian Harta Bersama Pasca Perceraian: Studi Kasus Perkawinan Poligami. SIGn ' 'Jurnal Hukum, CV. Social Politic Genius (SIGn), 1(2), hlm. 104 - 118. doi: https://doi. ' I org/10.37276/sjh.v1i2.60 